\title{
PERAN HUKUM ADAT DALAM PENYELESAIAN KASUS- KASUS KEKERASAN TERHADAP PEREMPUAN DI KUPANG, ATAMBUA, DAN WAINGAPU
}

\section{Tien Handayani Nafi, Lidiwina Inge Nurtjahyo, Iva Kasuma, Tirtawening Parikesit, dan Gratianus Prikasetya Putra}

\footnotetext{
* Dosen Fakultas Hukum Universitas Indonesia, Depok Korespondensi: lidwina.nurtjahyo@gmail.com Naskah dikirim: 23 Oktober 2015

Naskah diterima untuk diterbitkan: 5 April 2016
}

\begin{abstract}
This paper describes the intervention of customary law in the resolution of cases of violence against women and children - especially the intervention that is considered to be able to give justice to the victims. Settlement cases selected by the families of the victims of the indigenous peoples are not limited to cases which are brought to the formal judicial forum. Non-formal mechanisms (through elders) often provide resolution forums. Kupang, Atambua, and Waingapu become the communities that still choose traditional institutions in resolving the case as option, including in resolving some cases of violence against women. Figures of violence against women in those areas are also quite high (in 2012 recorded 478 cases based on data from the National Commission on the Rights of Women and Children). This research is based on the perspective of socio-legal studies, especially the anthropology of law. Studying law with using interdisciplinary approaches, in order to enrich the legal studies with mainstream perspectives.
\end{abstract}

Keywords: domestic violence, gender, women

\begin{abstract}
Abstrak
Tulisan ini menggambarkan intervensi hukum adat dalam penyelesaian kasus-kasus kekerasan terhadap perempuan dan anak - secara khusus yang dianggap dapat memenuhi rasa keadilan korban. Penyelesaian kasus yang dipilih oleh keluarga korban pada masyarakat adat tidak terbatas pada forum peradilan formal saja. Mekanisme non formal (melalui tetua adat) juga kerap menjadi forum penyelesaian. Dari sekian banyak komunitas adat di Indonesia, masyarakat adat di NTT, yaitu di Kupang, Atambua, dan Waingapu menjadi salah satu komunitas yang hingga kini masih memilih lembaga adat dalam menyelesaikan kasus, termasuk kekerasan terhadap perempuan. Angka kekerasan terhadap perempuan di wilayah tersebut juga cukup tinggi (tahun 2012 tercatat
\end{abstract}


478 kasus berdasarkan data dari Komisi Nasional Hak Asasi Perempuan dan Anak). Penelitian ini berada dalam genre socio-legal studies, khususnya antropologi hukum, yaitu studi hukum dengan pendekatan interdisipliner, sebagai suatu pengayaan terhadap studi hukum arus utama.

Kata kunci: kekerasan dalam rumah tangga, gender, perempuan

\section{Pendahuluan}

Pada masyarakat adat Indonesia, ada nilai-nilai dalam adat yang masih berlaku secara signifikan. Akan tetapi seiring dengan perkembangan dalam masyarakat, nilai-nilai tersebut juga dimaknai ulang oleh anggota masyarakat tersebut. Pemaknaan ulang tersebut memberikan dampak yang beragam. Salah satu contohnya adalah pemaknaan ulang yang dilakukan oleh anggota masyarakat adat di Nusa Tenggara Timur terhadap 'belis'. Di Nusa Tenggara Timur, dikenal sistem belis dalam meminang. Belis, diumpamakan sebagai mahar. Bentuk belis yang ditetapkan itu terdiri dari mata uang logam (terbuat dari emas, perak, maupun tembaga), ternak (kerbau dan babi), kain tenun. Pada praktik selanjutnya, akibat dari perkembangan yang terjadi di dalam masyarakat, sistem belis ini kemudian diberi makna berbeda. Belis, justeru menempatkan perempuan tidak ubahnya komoditas dagang. Perempuan yang akan dinikahi, seolah-olah diberi harga tertentu oleh keluarganya. Harga tersebut yang harus dibayar oleh pihak laki-laki.

Banyak kasus kemudian terjadi di tengah masyarakat akibat dari pemberlakuan belis ini, Pertama, anggota masyarakat yang menghindari penebusan belis melakukan kawin lari dan keluar dari kampungnya. Mereka melakukan hal tersebut disebabkan karena tingginya belis yang ditetapkan oleh adat. Akibat kedua, kehidupan perempuan yang menikah di luar wilayah adat menjadi amat rentan. Mereka sering menjadi korban kekerasan karena pada umumnya suami menganggap telah lepas dari kewajiban adat dan merasa bebas dan berhak melakukan kekerasan pada istrinya tanpa diberatkan oleh sanksi adat.

Di sisi lain, perempuan yang menikah secara adat dan tetap tinggal di dalam lingkup masyarakat adatnya juga rentan terhadap kekerasan. Kerentanan tersebut disebabkan oleh beberapa hal. Pertama, suami yang membayarkan belis merasa telah membayar lunas untuk memperoleh isterinya. Akibatnya suami sering bertindak semena-mena terhadap isteri, termasuk juga melakukan kekerasan. Kedua, dari aspek masyarakat adat sendiri, ada hal justru melestarikan tindak kekerasan yang dilakukan lakilaki terhadap perempuan. Tidak jarang sanksi adat yang dijatuhkan oleh tetua adat juga tidak menghiraukan kepentingan perempuan yang menjadi korban. Misalnya, dalam kasus kekerasan seksual berbentuk perkosaan, seringkali perempuan korban perkosaan dinikahkan dengan pelaku. Pertimbangannya adalah semata untuk menebus kesalahan dan 
menjaga keseimbangan kosmik, serta menutup aib bagi keluarga perempuan. Tentu hal ini menimbulkan permasalahan baru bagi perempuan korban.

\section{Permasalahan}

Paparan di atas merupakan pengantar untuk masuk ke masalah yang dipaparkan dalam tulisan ini. Adapun rumusan masalahnya adalah bagaimanakah peran hukum adat dalam upaya penyelesaian kasus kekerasan terhadap perempuan di tiga daerah di propinsi Nusa Tenggara Timur, yaitu Kupang, Atambua dan Waingapu?

\section{Metode Penelitian}

Data yang digunakan dalam tulisan ini merupakan sebagian dari data yang diperoleh dalam penelitian berjudul "Kajian Penyelesaian Kasus-Kasus Kekerasan terhadap Perempuan Melalui Mekanisme Hukum Adat: Studi Kasus di Kupang dan Atambua, NTT" serta "Kajian Penyelesaian Kasus-Kasus Kekerasan terhadap Perempuan Melalui Mekanisme Hukum Adat: Studi Kasus di Pulau Sumba, NTT". Pemilihan ketiga tempat tersebut sebagai lokasi penelitian disebabkan karena menurut data dari Catatan Tahunan Komisi Nasional untuk Hak Asasi Perempuan dan Anak (Catahu Komnas Perempuan), NTT merupakan salah satu propinsi di mana angka kekerasan terhadap perempuan dan anak mencapai jumlah yang cukup tinggi.

Adapun pengumpulan data dalam penelitian ini dilakukan dengan beberapa metode. Pertama, studi literatur dengan melakukan pengumpulan data sekunder dari lembaga layanan untuk mengkaji berbagai kebijakan tentang prosedur penanganan bagi perempuan bagi perempuan korban kekerasan di lembaga atau di masing-masing wilayah. Data sekunder ini digunakan selain untuk memberikan penjelasan mengenai tingginya jumlah kasus kekerasan terhadap perempuan, untuk memberikan penjelasan bahwa kasus kekerasan terhadap perempuan merupakan masalah yang pelik dan sangat urgen untuk diatasi, dan untuk membantu melengkapi temuan lapangan peneliti. Lembaga layanan yang dengan amat kooperatif bersedia mempersilakan peneliti memperoleh data sekunder tentang angka kasus kekerasan selain Komnas Perempuan, juga pihak Kepolisian Resor di tiga tempat. Untuk itu kami ucapkan terimakasih banyak kepada Wakapolres Kupang beserta Kanit PPA Polres Kupang, Kanit PPA Polres Belu beserta jajaran stafnya, serta Kapolres Waingapu beserta Kanit PPA dan Kasatreskrim Polres Waingapu. Tidak lupa ucapan terimakasih juga ditujukan untuk Rumah Aman Kupang, P2TP2A Kupang, Rumah Aman Atambua yang dikelola oleh Mama Folo, dan Yayasan Yasalti Waingapu. Terimakasih special juga kami tujukan kepada Suster Caecilia dan rumah amannya yang 
banyak membantu kami memahami lika liku peliknya upaya pemberdayaan korban kekerasan terhadap perempuan dan anak.

Kedua, data juga digali melalui apa yang disebut sebagai metode tutur perempuan'. Metode ini berisi proses menggali, mendengar dan merekam kisah-kisah para perempuan yang berkaitan dengan narasi besar dari peristiwa tertentu. Pengalaman perempuan dianggap sebagai informasi penting, sebagai upaya untuk mendekonstruksi pemahaman yang memposisikan pengalaman perempuan bukan sebagai pengetahuan. Selain dimaksudkan untuk memperoleh data, metode tutur perempuan juga bermakna dapat membantu perempuan terutama yang pernah menjadi korban kekerasan untuk didengar suaranya. Dengan demikian, mendengarkan tutur perempuan juga merupakan kegiatan yang bermakna bagi upaya penguatan perempuan itu sendiri. Akan tetapi yang amat istimewa, dalam penelitian ini informan tidak hanya para ibu penyintas maupun korban kekerasan dalam rumah tangga, ada pula seorang bapak yang berupaya menyelamatkan nasib anaknya yang menjadi korban kekerasan seksual yang dilakukan oleh adik kandung dari ibu anak tersebut.

Terakhir tetapi tidak kalah penting, peneliti juga melakukan pengamatan terlibat. Tidak hanya mengamati berbagai kegiatan dan situasi yang ada berkaitan dengan korban maupun lembaga layanan, peneliti juga turut serta tinggal di lingkungan tersebut. Terlibat dengan berbagai acara yang diselenggarakan.

Dalam penelitian ini tidak ditemukan hambatan yang berat kecuali masalah biaya transportasi. Berpergian ke wilayah Indonesia Timur memang memerlukan biaya yang lebih besar dibanding dengan apabila melakukan penelitian hanya di wilayah Indonesia Barat. Akan tetapi tantangan untuk mengeksplorasi Indonesia Timur yang kaya dengan nilai-nilai adat dan juga keunikan alamnya, mengalahkan beratnya biaya transportasi bagi peneliti. Masalah yang dihadapi oleh perempuan di Indonesia Timur juga cukup berat dan merupakan gunung es yang harus diungkap.

\section{Kerangka Konseptual dan Kerangka Teoritis}

Baik tulisan Bronislaw Malinowski tentang 'Crime and Custom in Savage Society' dan tulisan Ishaac Schapera tentang 'A Handbook of Tswana Law and Custom, ${ }^{1}$ menggambarkan tentang keberadaan hukum pidana dalam konteks masyarakat yang memiliki struktur pemerintahan yang khas. Aturan hukum pidana itu, dikonstruksi berdasarkan nilai-nilai yang dijunjung tinggi di dalam adat masing-masing kelompok masyarakat yang menjadi subyek penelitian baik Malinowski maupun Schapera. Kedua tulisan tersebut memberikan pemahaman bahwa

\footnotetext{
${ }^{1}$ Kedua artikel ini terdapat dalam buku "Law and Anthropology: A Reader", yang diedit oleh Sally Falk Moore.
} 
metode untuk melacak hukum pidana adat dalam masyarakat adat adalah dapat dilakukan antara lain melalui cara penelusuran kasus sengketa maupun sengketa yang diperluas. Sebagai catatan, kejahatan dalam konteks hukum adat pada kedua masyarakat ini,sanksinya selain mengandung hukuman bagi si pelaku, juga memberi semacam ganti rugi untuk korban/keluarganya sebagai sarana untuk memenuhi rasa keadilan masyarakat setempat dan untuk memulihkan kerusakan yang timbul akibat dari kejahatan yang dilakukan oleh si pelaku.

Menarik untuk mengetahui bagaimana suatu masyarakat menangani kasus kekerasan terhadap perempuan karena dari cara penanganannya - yang merupakan pelaksanaan dari aturan hukum yang dikonstruksi masyarakat tersebut - dapat terlihat bagaimana kedudukan perempuan dalam masyarakatnya. Akan dapat digali juga bagaimana masyarakat mempersepsikan perempuan dan laki-laki; bukan hanya dari konteks jenis kelaminnya melainkan juga dari aspek gendernya, lewat mekanisme penyelesaian kasus kekerasan terhadap perempuan.

Kekerasan terhadap perempuan sendiri sejatinya termasuk dalam kekerasan berbasis gender yang menimpa anak dan perempuan. Lingkup dari GBV ini antara lain sebagaimana dikemukakan oleh Jeanne Ward:

( $G B V$ refers to) any harm that is perpetrated against a person's will; that has a negative impact on the physical or physicological health, development, and identity of the person; and that is the result of gender powered inequities that exploit distinctions between males and females, among males and among females. Although not exclusive to women and girls, GBV principally affects them across all cultures. Violence may be physical, physicological, economic or sociocultural (savethechildren.org. hlm. 12).

Tina Johnson dalam tulisannya menyebutkan (2004:1) bahwa GBV adalah kekerasan yang dilakukan terhadap individu berdasarkan gendernya. Salah satu di antara bentuk GBV adalah perkosaan dan kejahatan seksual lainnya. Kebanyakan korban berasal dari kelompok perempuan dan anak perempuan meskipun laki-laki dan anak laki-laki dapat pula menjadi korbannya. Tempat terjadinya kekerasan berbasis gender ini sangat tak terbatas: pada ruang publik maupun privat.

Deklarasi PBB tentang Penghapusan Kekerasan terhadap Perempuan secara khusus menggambarkan bahwa kekerasan terhadap perempuan adalah:

A manifestation of historically unequal power relations between men and women, which have led to domination over and discrimination against women by men and to the prevention of the full advancement of women and as one of 
the crucial social mechanisms by which women are forced into a subordinate position compared with men.

Kekerasan terhadap perempuan dan anak, menurut beberapa kutipan literatur di atas merujuk pada terjadinya tindakan kekerasan yang dilakukan lebih karena status gender dan usia yang menimbulkan relasi yang timpang antara pelaku dan korban. Dalam beberapa kasus, ketimpangan relasi ini diperkuat dengan kesenjangan status sosial dan ekonomi antara pelaku dan korban. Jadi penting untuk dipahami bahwa kekerasan berbasis gender termasuk juga kekerasan seksual di dalamnya terjadi bukan melulu karena masalah dorongan hasrat seksual melainkan lebih merupakan pernyataan kekuasaan seseorang atau kelompok terhadap orang atau kelompok lainnya.

Untuk melihat bagaimana produk hukum Negara menyediakan mekanisme penanganan bagi kasus-kasus kekerasan berbasis gender di Indonesia, penting untuk dibahas beberapa produk peraturan dalam tulisan ini; antara lain KUHP, UUP KDRT, Konvensi CEDAW yang diratifikasi dengan UU No 7 Tahun 1984. Dapat disebutkan di sini beberapa pasal dalam KUHP yang menjadi perhatian penting terkait dengan isu penelitian:

Pertama, pasal-pasal yang mengatur tentang kejahatan seksual. Di antaranya pasal tentang perkosaan (Pasal 285, 286, 287, dan 288 KUHP), perbuatan cabul (pasal 289, 290, 291, 292 dan 294 KUHP) dan perbuatan melarikan anak gadis (332 KUHP).

Pasal 285

Barangsiapa dengan kekerasan atau ancaman kekerasan memaksa seorang wanita bersetubuh dengan dia di luar perkawinan, diancam karena melakukan perkosaan dengan pidana penjara paling lama dua belas tahun.

Pasal 286

Barang siapa bersetubuh dengan seorang wanita di luar perkawinan, padahal diketahui bahwa wanita itu dalam keadaan pingsan atau tidak berdaya, diancam dengan pidana penjara paling lama sembilan tahun.

Pasal 287

(1) Barang siapa bersetubuh dengan seorang wanita di luar perkawinan, padahal diketahuinya atau sepatutnya harus diduganya bahwa umurnya belum lima belas tahun, atau kalau umurnya tidak jelas, bahwa belum 
waktunya untuk dikawin, diancam dengan pidana penjara paling lama sembilan tahun.

(2) Penuntutan hanya dilakukan atas pengaduan, kecuali jika umur wanita belum sampai dua belas tahun atau jika ada salah satu hal berdasarkan pasal 291 dan pasal 294.

Pasal 288

(1) Barang siapa dalam perkawinan bersetubuh dengan seorang wanita yang diketahuinya atau sepatutnya harus diduganya bahwa yang bersangkutan belum waktunya untuk dikawin, apabila perbuatan mengakibatkan lukaluka diancam dengan pidana penjara paling lama empat tahun.

(2) Jika perbuatan mengakibatkan luka-luka berat, dijatuhkan pidana penjara paling lama delapan tahun.

(3) Jika mengakibatkan mati, dijatuhkan pidana penjara paling lama dua belas tahun.

Pasal 289

Barang siapa dengan kekerasan atau ancaman kekerasan memaksa seorang untuk melakukan atau membiarkan dilakukan perbuatan cabul, diancam karena melakukan perbuatan yang menyerang kehormatan kesusilaan, dengan pidana penjara paling lama sembilan tahun.

Pasal 290

Diancam dengan pidana penjara paling lama tujuh tahun

1. Barang siapa melakukan perbuatan cabul dengan seorang, padahal diketahuinya, bahwa orang itu pingsan atau tidak berdaya.

2. Barang siapa melakukan perbuatan cabul dengan seorang padahal diketahuinya atau sepatutnya harus diduganya, bahwa umurnya belum lima belas tahun atau kalau umurnya tidak jelas, yang bersangkutan belum waktunya untuk dikawin.

3. Barang siapa membujuk seseorang yang diketahuinya atau sepatutnya harus diduganya bahwa umurnya belum lima belas tahun atau kalau umurnya tidak jelas yang bersangkutan belum waktunya untuk dikawin, untuk melakukan atau membiarkan dilakukan perbuatan cabul, atau bersetubuh di luar perkawinan dengan orang lain. 
Pasal 291

(1)Jika salah satu kejahatan berdasarkan pasal 286, 287, 289 dan 290 mengakibatkan luka-luka berat, dijatuhkan pidana penjara paling lama dua belas tahun.

(2)Jika salah satu kejahatan berdasarkan pasal 286, 287, 289 dan 290 mengakibatkan kematian dijatuhkan pidana penjara paling lama lima belas tahun.

Pasal 292

Orang dewasa yang melakukan perbuatan cabul dengan orang lain sesama kelamin,yang diketahuinya atau sepatutnya harus diduganya belum dewasa, diancam dengan pidana penjara paling lama lima tahun.

Pasal 294

(1)Barang siapa melakukan perbuatan cabul dengan anaknya, anak tirinya, anak angkatnya, anak di bawah pengawasannya yang belum dewasa, atau dengan orang yang belum dewasa yang pemeliharaannya, pendidikannya atau penjagaannya diserahkan kepadanya ataupun dengan bujangnya atau bawahannya yang belum dewasa, diancam dengan pidana penjara paling lama tujuh tahun.

(2)Diancam dengan pidana yang sama:

1. Pejabat yang melakukan perbuatan cabul dengan orang yang karena jabatan adalah bawahannya, atau dengan orang yang penjagaannya dipercayakan atau diserahkan kepadanya.

2. Pengurus, dokter, guru, pegawai, pengawas, atau pesuruh dalam penjara, tempat pekerjaan Negara, tempat pendidikan, rumah piatu, rumah sakit, rumah sakit jiwa, atau lembaga sosial, yang melakukan perbuatan cabul dengan orang yang dimasukkan ke dalamnya.

Pasal KUHP yang mengatur tentang tindak pidana melarikan perempuan, diatur dalam KUHP pada Pasal 332:

(1)Bersalah melarikan wanita diancam dengan pidana penjara:

a. Paling lama tujuh tahun, barang siapa membawa pergi seorang wanita yang belum dewasa, tanpa dikehendaki orang tuanya atau walinya tetap dengan persetujuannya dengan maksud untuk memastikan 
penguasaan terhadap wanita itu, baik di dalam maupun di luar perkawinan;

b. Paling lama sembilan tahun, barang siapa membawa pergi seorang wanita dengan tipu muslihat, kekerasan atau ancaman kekerasan, dengan maksud untuk memastikan penguasaannya terhadap wanita itu, baik di dalam maupun di luar perkawinan.

(2) penuntutan hanya dilakukan atas pengaduan

(3)pengaduan dilakukan:

a. jika wanita ketika dibawa pergi belum dewasa, oleh dia sendiri atau orang lain yang harus memberi izin bila dia kawin;

b. jika wanita ketika dibawa pergi sudah dewasa, oleh dia sendiri atau oleh suaminya.

(4) Jika yang membawa pergi lalu kawin dengan wanita yang dibawa pergi dan terhadap perkawinan itu berlaku aturan-aturan Burgerlijk Wetboek, maka tak dapat dijatuhkan pidana sebelum perkawinan itu dinyatakan batal.

Selain KUHP, tulisan ini juga mengangkat beberapa pasal dalam UUP KDRT.Ada tiga pasal dalam UU ini yang dirujuk. Pertama pasal 1 tentang definisi KDRT. Kedua, pasal 5 tentang bentuk kekerasan fisik. Ketiga, Pasal 8 tentang cakupan kekerasan seksual sebagaimana dimaksud dalam Pasal 5 huruf $\mathrm{c}$ dari UU tersebut.

\section{Pasal 1 UUP KDRT}

Dalam Undang-Undang ini yang dimaksud dengan:

1. Kekerasan dalam Rumah Tangga adalah setiap perbuatan terhadap seseorang terutama perempuan, yang berakibat timbulnya kesengsaraan atau penderitaan secara fisik, seksual, psikologis, dan/atau penelantaran rumah tangga termasuk ancaman untuk melakukan perbuatan, pemaksaan, atau perampasan kemerdekaan.

Pasal ini menjelaskan tentang kekerasan yang terjadi di dalam keluarga. Pasal 1 UU ini kemudian dijelaskan dengan lebih terinci dalam Pasal 5 UU PKDRT.

\section{Pasal 5}

Setiap orang dilarang melakukan kekerasan dalam rumah tangga terhadap orang dalam lingkup rumah tangganya, dengan cara:

a. kekerasan fisik;

b. kekerasan psikis; 
c. kekerasan seksual; atau

d. penelantaran rumah tangga.

Kekerasan fisik mencakup bentuk kekerasan yang dilakukan dengan tindakan yang berakibat pada terjadinya luka secara temporer ataupun permanen ataupun cacat, bahkan kematian.

Kekerasan psikis adalah kekerasan yang dilakukan dalam bentuk ancaman, intimidasi, penghinaan yang menimbulkan trauma, perasaan takut, perasaan rendah diri pada korban, hilangnya rasa aman. Kekerasan seksual - dalam tulisan ini disebut sebagai kejahatan seksual merupakan kekerasan yang menyerang seksualitas perempuan dan anak, dapat berupa perkosaan, perundungan seksual, sodomi, pelecehan seksual dengan menggunakan kata-kata, dan sebagainya. Penelantaran rumah tangga, sebagaimana dimaksud dalam pasal ini, merupakan bentuk kekerasan yang terjadi dalam bidang ekonomi. Butir ini ditafsirkan terjadi apabila suami sebagai kepala keluarga menelantarkan anak dan isterinya dengan cara tidak memberikan nafkah.

Penjelasan lebih lanjut mengenai bentuk kekerasan seksual dalam Pasal 5 UU PKDRT hadir dalam Pasal 8 dari UU ini.

\section{Pasal 8}

Kekerasan seksual sebagaimana dimaksud dalam Pasal 5 huruf c meliputi:

a. pemaksaan hubungan seksual yang dilakukan terhadap orang yang menetap dalam lingkup rumah tangga tersebut;

b. pemaksaan hubungan seksual terhadap salah seorang dalam lingkup rumah tangganya dengan orang lain untuk tujuan komersial dan/atau tujuan tertentu.

Berdasarkan hasil pencatatan Komnas Perempuan terhadap tindak kekerasan terhadap perempuan tahun 2012 terdapat 1164 kasus yang terjadi di Nusa Tenggara.1 Di wilayah NTT sendiri tercatat ada 478 kasus.

Studi mengenai penyelesaian kasus KDRT di wilayah NTT juga pernah dilakukan oleh Lamber Missa. ${ }^{2}$ Hasil penelitiannya menunjukkan bahwa apapun bentuk penyelesaiannya, tindak kekerasan dalam rumah tangga jika dilihat dari aspek kriminologi tetap dipandang sebagai tindak criminal, oleh karena itu penyelesaiannyapun tetap berpedoman pada hukum pidana, misalnya penyelesaian secara adat berupa taloitan tafani tetap menerapkan sanksi pidana berupa denda sebagai salah satu upaya

2 Tesis berjudul Studi Kriminologi Penyelesaian Kasus Kekerasan Dalam Rumah Tangga diWilayah Kupang Nusa Tenggara Timur (Universitas Diponegoro Semarang Jawa Tengah 2010). 
pemulihan nama baik, serta harkat dan martabat, terutama perempuan sebagai korban. Faktor terjadinya KDRT ditinjau dari aspek kriminologi menjadi fokus dari riset itu. Namun demikian, penelitian ini tidak merefleksikan pengalaman perempuan korban KDRT, sehingga bagaimana perempuan memaknai berbagai forum penyelesaian kasus tidak terungkap.

Sebelum masuk ke pembahasan temuan dan analisis hasil penelitian, ada dua konsep lagi yang penting untuk dipaparkan, yaitu konsep tentang konflik dan sengketa. Sering kedua konsep ini dipertukarkan penggunaannya tanpa diketahui makna sebenarnya. Adapun konflik terjadi apabila seseorang atau suatu kelompok merasa dirinya dirugikan oleh pihak lain (Nader dan Todd, 1971). Pihak yang merasa dirugikan kemudian mengajukan keluhan kepada pihak yang dianggap merugikan. Oleh Abel, Sarat, dan Felstiner (1980/1981) kondisi ini disebut sebagai blaming, yaitu tahap di mana seseorang atau suatu kelompok yang merasa dirugikan sudah dapat mengenali kerugian yang dialaminya dan mengetahui pihak yang dianggap menyebabkan kerugian tersebut.

Sengketa adalah kondisi di mana pihak yang merasa dirugikan itu sudah mengajukan keluhannya kepada pihak yang dianggap merugikan namun tidak mendapat tanggapan yang layak menurut perspektif pihak yang dirugikan. Akibatnya pihak yang merasa dirugikan membawa keluhan/kasusnya ke pihak ketiga (Nader dan Todd, 1971). Abel, Sarat dan Felstiner (1980/1981) memberi istilah claiming pada tahapan ini di mana pihak yang dirugikan berupaya untuk melakukan claim supaya mendapat remedies atau ganti rugi yang adil atas kerugian yang dideritanya.

Dalam kasus kekerasan terhadap perempuan, dapat saja dikatakan bahwa konflik terjadi ketika melibatkan perempuan dan pelaku dan sengketa terjadi ketika korban sudah membawa kasusnya kepada pihak ketiga. Akan tetapi dalam kasus kekerasan yang menimpa perempuan terutama dalam konteks penelitian ini, biasanya korban tidaklah tunggal dalam arti bukan hanya perempuan yang bertindak sebagai korban melainkan keluarganya juga. Menempatkan kasus kekerasan terhadap perempuan dalam konteks konflik atau sengketa menjadi cukup sulit karena begitu kasus kekerasan terungkap maka keluarga sebagai pihak ketiga dapat berperan melebur ke dalam salah satu pihak atau justru menjadi pihak ketiga.

\section{Temuan}

Pada bagian ini dipaparkan beberapa temuan tentang bagaimana peran hukum adat menyelesaikan kasus-kasus kekerasan terhadap perempuan. Untuk itu tidak hanya digambarkan tentang mekanisme penyelesaiannya, melainkan juga pandangan masyarakat di lokasi penelitian tentang posisi perempuan. 


\section{Kupang dan Atambua}

Menurut data yang diperoleh dari para informan di Kupang dan Atambua, kasus kekerasan terhadap perempuan khususnya isteri terjadi karena adanya perubahan perspektif terhadap belis. Belis tadinya bermakna bahwa untuk mendapatkan isteri itu tidaklah mudah untuk itu perempuan harus dihargai (demikian menurut informan kami Ibu Maria Louis dan kanit PPA Polres Kupang). Akan tetapi dalam perjalanan waktu terdapat pergeseran makna dari belis itu. Pihak laki-laki karena merasa telah mengeluarkan sejumlah uang untuk dapat menikahi perempuan, menganggap bahwa perempuan telah menjadi miliknya ketika sudah berstatus isteri. Sering terjadi bahwa kasus-kasus kekerasan terhadap isteri di dalam rumah tangga disebabkan karena si laki-laki menganggap bahwa isterinya adalah milik yang dapat diperlakukan seenaknya. Ketika isteri dianggap tidak lagi memenuhi kriteria suami, maka dapat saja isteri menerima tindak kekerasan atau penelantaran atau diperlakukan sesuka hati suami. Misalnya tergambar dari kasus yang diceritakan Ibu Maria Louis.

Ada kenalan kami, seorang ibu. Dia ditelantarkan suaminya. Bekerja keras mengurus anak, urus rumah dan masih kerja juga jadi guru. Tapi suaminya main gila sama teman sekantornya (teman suami). Ketika dipanggil dan dinasehati oleh atasan, suaminya membela diri 'eh itu sudah saya belis, tapi dia tak rawat diri. Badan so bau, rambut segini (sambil memperagakan rambut keriting dengan tangan di samping kepala), sonde (tidak) menariklah! Buat apa?

Di Kupang dan Atambua masalah (lasi) kekerasan dalam rumah tangga ataupun kekerasan terhadap perempuan dimungkinkan untuk diselesaikan secara adat. Akan tetapi berdasarkan temuan penelitian, pilihan perempuan untuk menyelesaikan kasus yang dihadapinya secara adat lebih sering terjadi di Atambua dibandingkan dengan di Kupang.

Pada kasus kekerasan yang terjadi di Kupang, contohnya kasus pembunuhan isteri dan kasus pemukulan dan penelantaran isteri, penyelesaian dilakukan pihak keluarga ataupun korban melalui jalur hukum negara. Keluarga korban melapor kepada pihak kepolisian yang kemudian segera melakukan penyidikan terhadap kasus tersebut. ${ }^{3}$

Di Atambua, terdapat beberapa kasus kekerasan terhadap perempuan yang diselesaikan secara adat dan ada pula kasus kekerasan yang diselesaikan melalui jalur hukum negara. Contoh

${ }^{3}$ Hasil wawancara dengan Wakapolres dan Kanit PPA Kupang tentang pilihan warga untuk menyelesaikan kasus kekerasan terhadap perempuan. 
kasus kekerasan yang diselesaikan secara adat misalnya kasus suami yang diam-diam meninggalkan isterinya, kasus pemukulan isteri, kasus perselingkuhan. Contoh kasus kekerasan yang diselesaikan melalui jalur hukum negara antara lain kasus perkosaan yang menimpa seorang anak berusia 12 tahun dan kasus pembunuhan isteri.

Pada kasus kekerasan terhadap perempuan, apabila korban ataupun keluarga korban memilih mekanisme penyelesaian secara adat, ada beberapa bentuk yang berbeda. Untuk kekerasan fisik, denda adatnya berupa sopi, ternak babi dan kain tenun. Maknanya adalah pelaku memohon maaf atas tindakan tersebut. Tidak hanya permintaan maaf, pemberian kain tenun merupakan simbolisasi dari adanya harapan supaya ikatan kekeluargaan yang rusak dapat dipulihkan kembali.

Berbeda halnya pada kasus kekerasan psikologis. Denda yang sama yaitu sopi, ternak babi dan kain tenun dimaksudkan sebagai permintaan maaf dan pepulih. Pemberian benda-benda itu juga bermakna bahwa korban akan mendapatkan kembali kepercayaan dirinya.

Pelaku kekerasan penelantaran atau kekerasan ekonomi akan mendapat ganjaran yang sama juga berupa sopi, tenun dan ternak babi hanya saja jumlahnya berbeda dengan denda yang dikenakan terhadap pelaku kekerasan fisik maupun psikologis. Makna dari denda ini adalah pelaku insyaf dan akan berkumpul lagi bersama keluarganya.

Paling menarik adalah hukuman yang dikenakan terhadap pelaku kekerasan seksual. Pelaku justru akan dinikahkan dengan korban atau apabila korban menolak maka kasus ini akan dibiarkan menggantung. Penyelesaian macam ini tentu saja merugikan korban. Akibatnya, kekerasan bentuk ini jarang diselesaikan secara adat. Korban memilih untuk pergi ke jalur hukum negara. Akan tetapi pilihan korban untuk menyelesaikan kasus kekerasan seksual yang dihadapinya tidak luput dari dorongan pihak keluarga. Peneliti selama melaksanakan kegiatan wawancara jarang sekali mendengar kisah tentang kekerasan yang kemudian dilaporkan oleh korban ke polisi tanpa adanya dukungan keluarga di belakang korban.

Pada kasus-kasus kekerasan seksual di mana korban adalah orang yang sebatang kara atau tidak didukung oleh keluarganya, peneliti tidak mendapatkan informasi bahwa kasus tersebut dilaporkan kepada pihak kepolisian. Contohnya kasus penganiayaan anak perempuan usia 12 tahun di Waingapu yang menjadi korban kekerasan seksual dari keluarga angkatnya ataupun perempuan yang dipasung oleh keluarganya yang menjadi korban kekerasan seksual dari salah seorang kerabat tokoh elit di daerah itu. Kekerasan tersebut tidak dilaporkan kepada pihak kepolisian, 
bahkan korban dibiarkan jatuh pingsan sampai ditemukan orang lain yang bersimpati dan membawa mereka untuk dirawat.

Dalam penelitian di Atambua, ditemukan adanya kasus perkosaan yang menimpa seorang anak bernama S. Tindakan kejahatan itu dilakukan oleh paman korban sendiri. Ayah korban meskipun didesak oleh keluarga besar untuk menyelesaikan kasus tersebut secara adat dengan alasan bahwa pelaku adalah keluarga korban sendiri, menolak penyelesaian melalui hukum adat. Sang ayah membawa kasus ini kepada polisi. Sampai saat ini kasus masih dalam penyidikan. Harapan sang ayah hanyalah bahwa pelaku dihukum seberat-beratnya dan si anak tetap dapat diperbolehkan bersekolah meskipun ia sudah hamil. Pihak kepolisian langsung melakukan tindakan penangkapan terhadap pelaku. Keluarga korban bahkan sempat memberi informasi kepada peneliti setelah enam bulan peneliti pergi dari lapangan, tentang perkembangan kasus mereka yang pada saat ini sedang dalam tahap penyidikan oleh pihak Kejaksaan Negeri.

Beberapa kasus kejahatan berat terhadap perempuan, diselesaikan baik secara adat maupun melalui mekanisme penyelesaian yang terdapat dalam hukum Negara. Dapat disebutkan dua contoh di sini di mana digunakan denda adat dan sekaligus juga pelaku diproses secara hukum (Negara). Misalnya dalam kasus pembunuhan isteri baik di Kupang maupun di Atambua, pelaku pada masing-masing kasus dilaporkan oleh keluarga korban ke polisi. Pada kasus yang terjadi di Atambua, korban adalah isteri dan anak dari si pelaku. Baik isteri maupun anak yang masih balita dipenggal oleh sang suami, dan jasad mereka dibiarkan tergeletak di suatu tempat terpencil. Setelah keluarga korban berhasil menemukan korban dan anaknya, pelaku dilaporkan kepada polisi dan juga kepada tokoh adat. Akhirnya pelaku diproses secara hukum negara dan terhadap pelaku dan keluarganya dikenakan denda adat oleh masyarakat.

Hukuman ganda juga diterima oleh pelaku perkosaan terhadap anak kandung. Kasus ini terjadi di Belu. Sang ayah yang melakukan perkosaan secara berulang kepada tiga anak kandungnya berjenis kelamin perempuan, diadukan oleh keluarga besarnya kepada polisi. Selain akhirnya ditangkap dan diproses oleh polisi, pelaku juga dijatuhi hukuman adat berupa denda.

Dalam kasus ingkar janji nikah, di mana seorang perempuan hidup bersama dengan seorang laki-laki sampai mempunyai anak tanpa dia tahu bahwa laki-laki itu sebenarnya sudah menikah, perempuan tersebut tidak diuntungkan oleh putusan adat. Si perempuan yang sebetulnya dibohongi oleh laki-laki tersebut, justru menerima hukuman berupa harus membayar denda adat kepada keluarga isteri pelaku. 
Bentuk penyelesaian yang unik tanpa melalui hukum negara maupun hukum adat meskipun meminjam atribut hukum adat maupun hukum agama dan hukum negara, terjadi pada kasus perselingkuhan dan KDRT di Kupang. Seorang suami melapor ke Rumah Perempuan bahwa isterinya berselingkuh dan juga melakukan kekerasan terhadap dirinya dan anak-anaknya. Oleh Rumah Perempuan, kasus ini difasilitasi. Perempuan tersebut, pihak selingkuhannya dan pihak suami diminta membuat surat perjanjian dengan disaksikan toloh agama setempat (pendeta), tokoh adat, pihak Rumah Perempuan dan polisi. Surat perjanjian tersebut dibuat di atas kertas bermeterai.

\section{Waingapu}

Masyarakat Sumba Timur, khususnya di Waingapu, terbagi dalam tiga golongan yaitu:

1) Maramba, adalah strata paling tinggi yang terdiri atas para bangsawan. Golongan ini adalah golongan yang paling berpengaruh di masyarakat. Keputusan penting selalu diambil oleh golongan ini;

2) Kabihu, yaitu golongan tengah;

3) Hamba, yaitu golongan terendah dan biasanya menjadi pelayan golongan Maramba.

Golongan Maramba dibagi lagi menjadi tiga golongan:

1) Umbu Memang, adalah orang atau keluarga yang secara turuntemurun memang keturunan bangsawan;

2) Umbu China, adalah orang Cina yang memiliki modal. Dia menjadi umbu karena memiliki modal besar dan bahkan bisa mengambil alih harta masyarakat setempat. Misalnya, hewan ternak dibeli semua oleh orang cina sehingga pada akhirnya masyarakat setempat menjadi gembala ternak yang sudah dimiliki oleh orang keturunan Cina tersebut;

3) Umbu Kola, adalah orang yang menjadi umbu karena bersekolah. Akan tetapi secara politik, orang yang menjadi umbu karena pendidikan sering tidak dianggap secara adat. "Kalau dia ngomong, hanya akan dianggap sebelah mata saja karena yang paling didengar sebetulnya adalah umbu yang memang dari keturunan". Demikian penuturan informan kunci kami, Rambu Ninu.

Salah seorang informan lain bernama Rambu Ami lalu bercerita mengenai kisah wakil bupati yang bepergian dengan supirnya ke suatu desa, untuk memperkuat gambaran tentang betapa pentingnya asal usul keturunan ini dalam masyarakat Sumba Timur. Wakil bupati secara strata sosial satusnya lebih 
rendah dibandingkan dengan supirnya yang berasal dari kalangan Umbu memang. Hal tersebut terlihat pada saat dihidangkan makanan dan minuman, cangkir dan piring yang disediakan untuk supir wakil bupati lebih bagus daripada cangkir dan piring yang disediakan untuk sang wakil bupati. "jadi secara adat, meskipun dia menduduki jabatan tinggi atau pendidikan tinggi, namun kalau strata sosialnya rendah, maka tidak akan dianggap sepenuhnya".

Bagaimana dengan kedudukan perempuan di dalam masyarakat Sumba Timur? Perempuan menurut Rambu Ninuk sebetulnya mempunyai suara khususnya dalam hal ekonomi namun tidak banyak di ruang publik. Laki-laki dalam konteks adat Sumba Timur adalah penguasa ruang publik. Para perempuan kurang bisa berekspresi di ruang publik tersebut. Akan tetapi sebetulnya, menurut informan bernama Rambu Ninuk perempuan sangat mengetahui tata cara proses penyelesaian konflik di dalam keluarga sehingga banyak persoalan yang bisa diselesaikan oleh perempuan secara kekeluargaan. Hal ini penting bagi mereka (menyelesaikan kasus secara kekeluargaan) karena jika sampai tersebar ke luar akan menjadi aib bagi keluarga mereka. Jadi perempuan itu sekaligus menjadi penjaga aib keluarga. Menurut Rambu Ninuk, seharusnya kasus seperti KDRT bisa diungkap karena sudah ada undang-undangnya namun karena hal ini masih dianggap aib, maka jika terjadi kasus akan diredam di dalam keluarga saja. ${ }^{4}$

Perempuan, menurut penuturan informan lain yang adalah seorang pendeta, sering juga malahan terlibat dalam kasus kekerasan sebagai pelaku. Jadi, di dalam konteks masyarakat Waingapu, kekerasan dapat terjadi dalam keluarga bukan hanya karena relasi kuasa yang timpang atas basis perbedaan gender ataupun jenis kelamin. Akan tetapi kekerasan dapat terjadi juga karena relasi kuasa yang timpang atas basis status sosial dan perbedaan usia.

Informan yang bernama Rambu Ninuk mengatakan bahwa kekerasan dalam keluarga sedapatnya akan diselesaikan dengan bantuan mediator yang harus berasal dari strata sosial yang sama atau lebih tinggi. Mediator ini pun biasanya berasal dari kalangan keluarga. Jika berasal dari strata sosial yang sama, maka ada faktor latar belakang pendidikan yang menjadi pertimbangan ketika memilih mediator. Jika berasal dari kelas menengah, maka mediator akan berasal dari kelas Maramba. Jika berasal dari kelas Hamba, otomatis mediator adalah kelas menengah atau Maramba. Jarang sekali terjadi jika masalah

\footnotetext{
${ }^{4}$ Berdasarkan wawancara Tim peneliti lapangan dengan Rambu Ami dan Rambu Ninuk pada Minggu,29 Juni 2014 di Hotel Tanto, Pulau Sumba NTT
} 
terjadi pada golongan Maramba, mediator berasal dari kelas yang di bawahnya.

Mediator juga ditentukan oleh suku mana yang berwenang untuk menyelesaikan konflik. Di kelas Maramba, terdapat suku-suku yang tidak semuanya berperan dalam penyelesaian konflik internal atau eksternal. Ada pembagian peran pada suku-suku tersebut, misalnya ada suku yang khusus untuk urusan tanah, ada yang untuk upacara adat kematian dan penguburan, ada yang untuk perkawinan, dan sebagainya. Dan peran ini sudah menjadi kewenangan suku tertentu secara turun temurun.

Seorang informan lainnya bernama Umbu Guntur menceritakan bahwa pernah dalam suatu seminar yang diadakan oleh Komnas Perempuan, salah seorang mantan bupati Sumba Timur mengatakan bahwa di Wilayah Sumba Timur tidak ada kekerasan terhadap perempuan. Tindakan yang dilakukan terhadap perempuan merupakan hal yang dilegalisasi oleh adat. Adat meletakkan perempuan pada struktur yang lebih rendah dibanding laki-laki, demikian juga dengan sistem kasta yang berlaku di mana perempuan dari kasta yang lebih rendah dianggap layak diperlakukan kasar atau menerima kekerasan karena di dalam adat memang dianggap sebagai bagian dari kebiasaan. Jadi dalam hal ini, perempuan terutama yang berada pada kelas atau strata rendah dalam masyarakat - akan rentan terhadap kekerasan ganda selain karena dia perempuan, juga karena dia berada pada posisi hamba.

Menurut Umbu Guntur pendapat bahwa kekerasan adalah bagian dari kebiasaan adalah tidak tepat karena banyak tetangganya yangi berstatus bangsawan memiliki banyak hamba namun diberikan pendidikan yang baik dan juga diberdayakan. Perlakuan baik atau buruk kepada perempuan khususnya yang berasal dari kasta yang lebih rendah tergantung pada pribadi masing-masing 'majikan'. Akan tetapi perbuatan sewenang-wenang yang dilakukan oleh majikan kepada hambanya memang sering terjadi.

Berkaitan dengan adanya persepsi bahwa kekerasan terhadap perempuan banyak terjadi akibat adanya aturan adat yang mengharuskan pemberian belis dari pihak keluarga lakilaki kepada keluarga perempuan, Umbu Guntur mencoba untuk menjelaskan tentang adat perkawinan di Sumba Timur.

Dalam proses perkawinan di Sumba Timur terdapat prosesi yang dinamakan acara 'ambil orang'. Esensi dari Acara ini adalah acara lamaran. Pada acara tersebut pihak keluarga laki-laki datang kepada keluarga perempuan memberikan belis dalam bentuk kerbau, kuda dan emas yang berbentuk vagina 
(mamuli). Di samping itu ada belis pendamping yaitu sapi. Sebaliknya pihak perempuan juga diwajibkan memberi balasan berupa kain kombu, sarung tenun dan babi. Jumlahnya harus seimbang. Maksud dari balasan belis tersebut ialah supaya keluarga laki-laki dan perempuan saling menghargai. Kalau belis tidak dibalas dengan seimbang akan menyebabkan pihak keluarga suami kurang menghargai pihak keluarga isteri, bahkan dapat berdampak pada terjadinya konflik di dalam rumah tangga. Beberapa tingkatan belis yang dikenal: belis putus (luhuliu purutana), belis kemoto, dan belis belum selesai.

Belis putus yang paling lazim terjadi di Sumba Timur. Dalam Belis putus, setelah belis dibayarkan secara tunai, perempuan harus keluar dari marganya dan masuk marga suaminya. Sebagai akibatnya perempuan lepas dari hak dan kewajibannya terhadap keluarga asalnya, dan dirinya menjadi hak dari keluarga suami. Apabila suami meninggal, isteri sepenuhnya akan menjadi tanggung jawab dari kerabat dan keluarga suami (termasuk juga anak-anak).

Pada belis belum selesai, belis dibayarkan oleh keluarga laki2 namun belum lunas. Keluarga perempuan masih punya hak 50\% jika suami meninggal sehingga dapat mengambil kembali si perempuan.

Belis kemoto juga mirip dengan belis belum lunas. Perempuan dapat diambil lagi oleh keluarganya apabila suami meninggal. Hal tersebut dapat dilakukan melalui pembicaraan adat antara keluarga perempuan dan keluarga almarhum lakilaki.

Umbu Guntur juga menceritakan bahwa di Waingapu kasus kekerasan terhadap perempuan biasanya adalah KDRT (suami terhadap isteri atau ayah terhadap anak atau umbu terhadap hamba) dan kasus kekerasan seksual (perkosaan). Sempat diceritakan pula bahwa dalam kasus-kasus semacam ini, penyelesaian di dalam keluarga diutamakan. Apabila tidak terdapat kesepakatan maka akan dibawa ke polisi. Dalam konteks Waingapu, dapat terjadi bahwa kasus yang sudah dibawa ke polisi masih diupayakan oleh para pihak untuk diselesaikan secara kekeluargaan meskipun polisi sudah melakukan proses penyidikan. ${ }^{5}$

Penyelesaian kasus kekerasan terhadap perempuan dan anak di Waingapu selain berdasarkan mekanisme hukum adat dan atau hukum Negara, ternyata juga menggunakan mekanisme lainnya. adapun yang disebut sebagai mekanisme lain itu adalah pembuatan semacam surat perjanjian di atas kertas bermeterai dan disaksikan selain oleh keluarga para

${ }^{5}$ Berdasarkan wawancara tim peneliti lapangan dengan Umbu Guntur pada Sabtu, 28 Juni 2014 di Bengkel Tolak Tambang, Pulau Sumba NTT 
pihak juga oleh para ketua adat, pemuka agama, Kepala Desa dan bahkan polisi. Di Desa Hambapraing, Sumba Timur, sebagai contoh terjadi perselingkuhan antara seorang lelaki yang telah berkeluarga dengan perempuan tetangganya yang juga sudah berkeluarga. Kasus perselingkuhan ini menimbulkan kemarahan pihak suami dari perempuan yang menjadi pelaku perselingkuhan. Suami tersebut mengadu kepada Ketua RT dan Kepala Desa setempat. Kemudian kasus tersebut akhirnya diselesaikan melalui surat pernyataan yang dibuat oleh kedua belah di depan Kepala Desa dan juga para saksi.

Dalam proses pembuatan Surat Pernyataan ini Ibu Bernadette lah yang mengundang para pihak beserta para tetua adat/tokoh adat, tokoh gereja, dan pejabat desa berwenang untuk berkumpul dan membuat surat pernyataan tersebut. Surat pernyataan itu dibuat rangkap dan disimpan oleh Kepala Desa, Ibu Bernadette, dan para pihak. Dalam hal ini kepolisian tidak ikut campur karena para pihak telah sepakat untuk menyelesaikan masalah ini melalui jalan perdamaian secara adat. Pada kasus yang diselesaikan melalui mekanisme surat pernyataan diatas, istri berselingkuh dengan pria lain yang masih lajang, kemudian sang suami melaporkan kepada kepala desa. Awalnya suami tidak mau rujuk kembali, namun dari pemerintah desa memberi nasehat agar diambil jalan terbaik dan jangan sampai terjadi untuk yang kedua kalinya. Lain kasus, apabila terjadi dalam sebuah kasus kekerasan pihak wanita pergi dan kembali ke pihak orang tuanya, maka pihak laki-laki harus membayar denda seperti hewan ternak atau emas kepada pihak keluarga perempuan. Untuk penyelesaian kasus-kasus melalui mekanisme perdamaian biasa dihadiri sampai 20 orang (Berdasarkan wawancara Tim peneliti lapangan dengan Ibu Bernadete pada Selasa, 1 Juli 2014 di Desa Hambapraing, Pulau Sumba NTT)

Selain di Hambapraing, kasus penganiayaan terhadap isteri di Desa Makamenggit pun diselesaikan melalui model perjanjian seperti di atas. Ada sebuah kasus dimana seorang suami memukul istrinya hingga babak belur. Suami memukul sang istri dalam kondisi mabuk seusai berkumpul dengan rekan-rekannya di sekitar rumah kediaman. Pada kasus tersebut akhirnya suami dilaporkan kepada kepolisian dan ditahan selama satu minggu. Setelah lewat satu minggu akhirnya pihak kepolisian melalui kepala desa membuat suatu pernyataan antar pelaku dan korban kekerasan dengan disaksikan oleh pihak kepala desa. Isi daripada pernyataan itu ialah perihal denda yang harus dibayar sang suami apabila melakukan tindak kekerasan terhadap istrinya. 


\section{Penutup Reflektif}

Pada kasus-kasus kekerasan yang menimpa perempuan di tiga daerah di NTT, terdapat beberapa mekanisme penyelesaian. Untuk kasus kekerasan psikologis atau dalam bentuk penelantaran keluarga, perempuan masih memilih untuk menyelesaikannya secara hukum adat. hal tersebut terjadi karena pernikahan oleh warga setempat masih dilihat bukan hanya sebatas mengikat pihak suami maupun isteri, melainkan juga keluarga besar pihak suami dan keluarga besar pihak isteri. Pilihan untuk menyelesaikan kasus secara hukum adat ditempuh untuk menghindari putusnya hubungan antara keluarga besar dan untuk meredam aib.

Dalam kasus kekerasan yang menimpa perempuan yang status sosialnya lebih rendah, pilihan penyelesaian tidaklah banyak dan amat tergantung pada kebijaksanaan dari pihak yang memiliki status sosial lebih tinggi. Di Waingapu misalnya, kekerasan yang terjadi pada hamba perempuan, penyelesaiannya akan amat tergantung pada rasa keadilan sang Umbu atau Rambu.

Di Kupang dan Atambua, kasus kekerasan yang berakibat fatal seperti misalnya pembunuhan ataupun perkosaan, oleh keluarga sebagian besar digiring ke ranah hukum negara.

Dalam konteks kasus kekerasan terhadap perempuan yang terjadi pada masyarakat di mana ikatan kekeluargaan masih kuat dan juga nilainilai sosial budaya masih dianggap mengikat, sesungguhnya masih dapat dikatakan ada opsi yang sangat variatif untuk memperoleh penyelesaian atas kasus tersebut. Seperti sudah dipaparkan sebelumnya, dalam penyelesaian kasus dapat saja untuk tindak pidananya, kasus diselesaikan dengan melalui mekanisme hukum Negara melalui cara melapor kepada polisi. Akan tetapi untuk aspek pemulihan hubungan antara keluarga pelaku dengan keluarga korban ataupun dengan masyarakat setempat maka mekanisme yang dipilih adalah yang berdasarkan hukum adat.

Di luar penyelesaian melalui mekanisme hukum adat atau mekanisme hukum negara atau dengan perpaduan keduanya untuk aspek yang berbeda dari kasus kekerasan terhadap perempuan, berdasarkan paparan di atas ternyata tersedia pilihan lain. Pilihan tersebut adalah pembuatan perjanjian kesepakatan antara pelaku dan korban yang ditandatangani kedua belah pihak di atas kertas bermeterai dan disaksikan para tokoh masyarakat baik tokoh agama, tokoh adat maupun pihak pemerintah setempat. Bentuk penyelesaian ini meskipun 'bungkus'-nya bersifat modern dalam bentuk surat perjanjian, tetapi melibatkan juga prinsip-prinsip hukum adat di dalamnya seperti 'terang' yaitu di hadapan publik, dan tunai - di mana usai surat perjanjian ditandatangani, denda juga harus dibayar dalam bentuk makan bersama. Biaya atau makanan untuk acara makan bersama itu disediakan oleh para pihak yang terlibat sengketa. Penting untuk dicatat bahwa bentuk perjanjian kesepakatan ini hanya dianjurkan oleh para tokoh yang kami 
wawancarai apabila kasus tersebut adalah kasus penganiayaan ringan dan KDRT yang bersifat psikologis, finansial, dan atau melibatkan kekerasan yang tidak berakibat fatal. Kasus perkosaan dan penganiayaan berat menurut para informan yang diwawancarai dalam penelitian ini, sedapat mungkin dibawa ke ranah hukum negara untuk penyelesaiannya meskipun ada juga beberapa kasus yang didengar tim peneliti 'lolos' baik dari jerat hukum negara maupun hukum adat karena pelaku termasuk dalam kelompok elit dalam masyarakat.

Dalam penelitian juga terungkap harapan para informan supaya tokoh adat yang memediasi kasus kekerasan terhadap perempuan dapat lebih berpihak pada korban. Untuk itu perlu ada sosialisasi lewat para ketua RT dan pemuka agama tentang UUPKDRT supaya para tokoh adat paham. Apabila tokoh adat paham, diharapkan mereka akan menasihati suami supaya paham dan dapat mengubah kebiasaannya juga. Selain itu pemuka adat maupun pemuka agama setempat hendaknya lebih sensitif dan adil terhadap kebutuhan perempuan yg menjadi korban sehingga jika ada korban yang datang, disambut dengan baik dan dilindungi.

Dari pihak keluarga korban ada harapan bahwa anak yang menjadi korban kekerasan seksual: hendaknya tidak dikawinkan dengan pelaku. Anak juga diharapkan tetap boleh melanjutkan pendidikan sekalipun hamil. 


\section{Daftar Pustaka}

Banakar, Reza and Max Travers. Introduction to Section One in Reza Banakar and Max Travers (ed.), "Theory and Method in SocioLegal Research”, Oxford and Portland Oregon: Hart Publishing, 2005.

Berenschot, Ward dan Adriaan Bedner. Akses terhadap Keadilan, Sebuah Pengantar tentang Perjuangan Indonesia Menjadikan Hukum Bekerja untuk Semua Orang, dalam "Akses terhadap Keadilan", Jakarta: KITLV, HuMa, VVI Leiden University, Epistema Institute, 2011

Bohannan, Paul J. Anthropology and the Law, in Sol Tax (ed.)., Horizons of Anthropology, Chicago: Aldine Publishing Company.

Edisi terjemahan Antropologi dan Hukum dalam T.O. Ihromi (ed.). "Antropologi dan Hukum", Jakarta: Yayasan Obor Indonesia, 1993.

Danandjaja, James. Folklor Indonesia Ilmu Gossip, Dongeng, dan lainlain. Jakarta: Grafiti, 1991.

Flood, John. Socio-legal Ethnography in Reza Banakar and Max Travers (ed.), "Theory and Method in Socio-Legal Research", Oxford and Portland Oregon: Hart Publishing, 2005.

Felstiner, William L., Richard L. Abel, dan Austin Sarat. 'The Emergence and Transformation of Disputes: Naming, Blaming, and Claiming", Law and Society Review", 15: 3/4 (1980/1981).

Harkrisnowo, Harkristuti. "Rekonstruksi Konsep Pemidanaan: Suatu Gugatan Terhadap Proses Legislasi dan Pemidanaan di Indonesia”, (Orasi Upacara Pengukuhan Guru Besar Tetap dalam Ilmu Hukum Pidana FHUI). Depok: Balai Sidang UI, 8 Maret 2003.

Holleman, J.F. Trouble-Cases and Trouble-Less Cases In The Study Of Customary Law And Legal Reform' dalam Keebeth von BendaBeckmann dan Foss Strijbosch, "Anthropology of Law in the Netherlands", Dordrecht: Foris Publications.

Ihromi, Tapi Omas. Kata Pengantar dalam T.O. Ihromi (ed.), "Antropologi dan Hukum", Jakarta: Yayasan Obor Indonesia, 1993..

Beberapa Catatan mengenai Metode Kasus Sengketa yang Digunakan dalam Antropologi Hukum, dalam T.O. Ihromi (ed.), "Bunga Rampai Antropologi Hukum", Jakarta: Yayasan Obor Indonesia, 1993. 
et.al. Laporan Akhir Tim Pengkajian Hukum tentang Penerapan Ketentuan Pidana Adat oleh Badan Peradilan. Jakarta: Departemen Kehakiman, Badan Pembinaan Hukum Nasional, 1997.

Malinowski, Bronislaw. Crime and Custom in Savage Society, dalam Sally Falk Moore (editor), "Law and Anthropology A Reader", Oxford: Blackwell Publishing: 2005.

Moeljatno. Kitab Undang-undang Hukum Pidana. Jakarta: Bumi Aksara, 1999.

Reksodiputro, Mardjono. Pembaharuan Hukum Pidana (Kumpulan Karangan Buku Keempat). Jakarta: Pusat Pelayanan Keadilan dan Pengabdian Hukum UI, 1997.

Schapera, Isaac. A Handbook of Tswana Law and Custom, dalam Sally Falk Moore (editor), "Law and Anthropology A Reader", Oxford: Blacwell Publishing: 2005.

Soekanto, Soerjono. Hukum Adat Indonesia. Cet.2. Jakarta: Rajawali Press, 1983.

Spradley, James P. Metode Etnografi (terjemahan Bahasa Indonesia). Yogyakarta: PT. Tiara Wacana, 1997.

von Benda-Beckmann, Franz. Who's Afraid of Legal Pluralism, "Journal of Legal Pluralism and Unofficial Law”, Commission on Legal Pluralism.: No 47/2002.

Keebet von Benda-Beckmann, Anne Griffiths. Space and Legal Pluralism: An Introduction, in Franz von Benda-Beckmann, Keebet von Benda-Beckmann, Anne Griffiths (eds.)., "Spatializing Law: An Anthropological Geography of Law in Society", Burlington: Ashgate Publishing Company, 2009.

Keebet von Benda-Beckmann, Anne Griffiths. Mobile People, Mobile Law: An Introduction, in Franz von BendaBeckmann, Keebet von Benda-Beckmann, Anne Griffiths (eds.)., Mobile People Mobile Law: Expanding Legal Relations in a Contracting World, Burlington: Ashgate Publishing Company, 2005. 